\title{
Red blood cell alloimmunization in multi-transfused patients with chronic kidney disease in Port Harcourt, South-South Nigeria
}

\author{
Esther Ifeoma Obi ${ }^{1}$, Crosdale Ogho Pughikumo ${ }^{2}$, Richard Ishmael Oko-jaja ${ }^{3}$
}

1. Department of Haematology and Blood Transfusion, Federal Medical Centre, Yenagoa, Bayelsa State, Nigeria.

2. Department of Haematology and Immunology, College of Health Sciences, Niger Delta University, Wilberforce Island, Bayelsa State, Nigeria.

3. Department of Internal Medicine, University of Port Harcourt Teaching Hospital, Port Harcourt, Rivers State, Nigeria.

\begin{abstract}
Background: Serological safety is an integral part of overall safety for blood banks.

Objectives: The aim of the study was to determine the prevalence and specificities of red blood cell alloimmunization in multi-transfused patients with chronic kidney disease (CKD).

Methods: A cross-sectional case-control study carried out at the University of Port Harcourt Teaching Hospital in which 186 patients with CKD were enrolled consecutively, 124 had received multiple transfusions (more than one unit of blood in one month, or at least 10 units within 3 months), while 62 had never been transfused. Antibody screen test was performed by the gel agglutination technique. RBC antibody identification was performed on the sera of those that tested positive to antibody screening test.
\end{abstract}

Results: Out of the 124 multi-transfused patients (total of 789 transfusions), 4 (3.2\%) were alloimmunised. The alloimmunised patients received a higher mean number of $17.5 \pm 12$ blood units, compared to $6 \pm 6$ units by the non-alloimmunised multi-transfused patient $(p=<0.001)$. Six clinically significant alloantibodies were identified with all of the alloimmunised patients forming more than one antibody. Anti-E was detected in all alloimmunised patients.

Conclusion: The prevalence of RBC alloimmunisation in multi-transfused $\mathrm{CKD}$ patients was $3.2 \%$ with anti-E being the most frequently identified antibody.

Keywords: Red blood cell alloimmunization, chronic kidney disease, Port Harcourt, South-south Nigeria.

DOI: https://dx.doi.org/10.4314/ahs.v18i4.18

Cite as: Obi EI, Pughikumo CO, Oko-jaja RI. Red blood cell alloimmunization in multi-transfused patients with chronic kidney disease in Port Harcourt, South-South Nigeria. Afri Health Sci. 2018;18(4): 979-987. bttps:/ / dx.doi.org/10.4314/abs.v18i4.18

\section{Introduction}

Blood transfusion is an integral part of the management of patients with chronic kidney disease (CKD) as severe anaemia is a feature of the late stages ${ }^{1}$. Chronic Kidney disease (CKD) is defined either as kidney damage/injury for $\geq 3$ months and/or glomerular filtration rate (GFR)

\section{Corresponding author:}

Esther Ifeoma Obi,

Department of Haematology and Blood

Transfusion, Federal Medical Centre, Yenogoa,

Bayelsa State, Nigeria.

Email: drs.rehtse@gmail.com
$<60 \mathrm{ml} / \mathrm{min}$ per $1.73 \mathrm{~m}^{2}$ for $\geq 3$ months with or without kidney damage. It is usually accompanied by features of uraemia, and a need for renal replacement therapy (which includes haemodialysis and/or kidney transplant) in its later stages. ${ }^{2,3,4}$ Management of renal anaemia include the use of erythropoiesis-stimulating agents (ESAs), blood transfusion as well as replacement of iron and other nutritional supplements. The decision to treat a patient with either an ESAs or blood transfusion is made on the threshold for transfusion. A high threshold includes a low haemoglobin level, usually less than $10 \mathrm{~g} / \mathrm{dl}$ or the presence of cardiac decompensation. ${ }^{3,4}$ In severe anaemia, immediate management may be blood transfusion to correct the anaemia in the short term. However, blood 
transfusion especially when given repeatedly may increase the risk of red cell alloimmunization. ${ }^{5}$

Red cell alloimmunization, is a humoral immune response which occurs when antibodies bind to foreign red cell antigens due to antigenic disparity between donor and recipient. Red cell alloimmunization may be induced by blood transfusion, pregnancy or organ transplantation. The consequences include delayed haemolytic transfusion reaction, difficulties in getting compatible blood for future transfusions, and a delay or failure in getting a kidney transplant. ${ }^{6,7}$ The incidence of red cell alloimmunization ranges between 1-6\% in single-transfused and up to $30 \%$ in multi-transfused patients (e.g., sickle cell disease, thalassaemia, haematological malignancies and ESRD). $8,9,10,11,12$ In Nigeria, where multiple ethnicities contribute to genetic heterogeneity among the population, a wide variety of antibodies are encountered. A study in Northern Nigeria reported a red cell alloimmunization prevalence of $8.8 \%$ in multi-transfused patients with sickle cell anaemia. ${ }^{13}$

In the United States, irregular RBC alloantibodies have been linked to the majority of fatal haemolytic transfusion reactions reported to the Food and Drug Administration (FDA), and are considered the second main cause of transfusion-related deaths ${ }^{14}$. Further studies have shown that prospective organ transplant recipients who received blood transfusions have an increased chance of having a high panel- reactive antibodies (PRA) score of greater than $80 \%$ compared to those who have never received blood transfusion. PRA is defined as the percentage of human leukocyte antigen (HLA) antigens singly or in combination out of a panel reacting with the patient's serum and may reflect the percentage of donors expected to react with the patient's serum. This finding has been associated with a longer wait to find a compatible donor and have completely precluded transplantation in some patients. $^{3,15}$

Pre-transfusion compatibility testing (PCT) in this environment does not include antibody screening and titration which determines the patient's antibody status as well as the severity of alloimmunization when present. Identification of the offending antibody can prevent further development of red blood cell alloantibodies as the patient is subsequently transfused with blood units free of the offending antigen.
Therefore, the main objective of this study was to assess the prevalence of red blood cell allommunization in multi-transfused patients with CKD in Port Harcourt, Nigeria.

\section{Methodology \\ Study population}

The study population consisted of 186 adult patients with chronic kidney disease defined by patients who have GFR $<60 \mathrm{ml} / \mathrm{min} / 1.73 \mathrm{~m}^{2}$ for $\geq 3$ months ${ }^{1}$, calculated using the modified diet in renal disease (MDRD) formula who had received multiple blood transfusions (more than one of blood within one month or at least 10 units of blood within 3 months), and adult patients with chronic kidney disease who had no history of blood transfusion. The study population were recruited consecutively from the nephrology out-patient clinic, medical outpatient clinics, as well as medical inpatients in UPTH.

Ethical approval was obtained from the hospitals' Ethics Committee and written consent was obtained from every patient before recruitment into the study. All the patients were routinely screened for HIV.

Inclusion criteria for the cases: Patients with CKD who were eighteen years and above; who had received multiple transfusions (more than one unit of whole blood within one month or at least 10 units of whole blood within 3 months).

Exclusion criteria for the cases: Patients with chronic kidney disease who were HIV positive and those with a history of kidney transplant.

Inclusion criteria for the controls: Patients with chronic kidney disease who were eighteen years and above; who have never been transfused.

Exclusion criteria for the control population: Patients with chronic kidney disease who had had a kidney transplant; and those who were HIV positive.

Sample analysis: Two milliliters of venous blood was collected into plain Vacutainer ${ }^{\circledR}$ bottles for Antibody screening, Antibody identification and titer determination. The serum was separated and stored in the freezer at $-20^{\circ} \mathrm{C}$ and analyzed weekly. The stored sera were thawed

African Health Sciences Vol 18 Issue 4, December, 2018 
and used for antibody screening by gel technology using commercially made panel of cells - "ID-Diacell I-IIIII ${ }^{\circledR}$ " lot number 45184.91.x for antibody screening and set of 11 "ID-DiaPanel®" Lot number 45161.40.x for antibody identification manufactured by Diamed $\mathrm{GmbH}$, Pra Rond 23, 1785 Cressier FR, Switzerland.

Antibody screening: Antibody screening test was performed on all study participants. Antibody screening test is not routinely done at UPTH as part of pre-transfusion testing. . The recipient's serum was combined with group O reagent red cells to allow for antigen/antibody interaction in the upper chamber of the microtube containing antiglobulin and low ionic strength saline (LISS) reagent. They were incubated at $37^{\circ} \mathrm{C}$. The gel card method is based on the principle of differential passage of agglutinated and free red cells through a dextran-acrylamide gel microtube column during controlled centrifugation. Agglutinated red cells become trapped in or above the gel. Unagglutinated red cells travel through the gel particles and form a pellet at the bottom of the microtube as shown in figure $1^{17}$.

Three panel of reagent red cells were used for antibody screening, and the antigenic specificity of the reagent red cells used included Rh (D,C,E,c,e,Cw); Kell (K,k,Kpa,kpb,Jsa,Jsb); Duffy (Fya, Fyb); kidd (Jka,Jkb); Lewis (Lea,Leb); P (P1); MNS (M,N,S,s); Lutheran (Lua,Lub); and $\mathrm{Xg}$

(Xga).
Red cell antibody identification was done using an antigram provided by the manufacturer. Eleven panel of reagent red cells were used for antibody screening with the above antigenic specificity. ${ }^{18}$

Antibody titration: Eleven tests tubes were labelled according to the serum dilutions: 1, 2, 4, 16, 32, 64, 128, 256, 512, 1024 and 2048. After preparing the master dilutions, titration was done using the gel cards following the same procedure above. ${ }^{19}$ To each of the gel card column, $50 \mu \mathrm{L}$ of well mixed reagent cells (for which the patients' serum tested positive during the antibody screening) was added. This was followed by $25 \mu \mathrm{L}$ of diluted serum sample. Incubation was done at $37^{\circ} \mathrm{C}$ and the gel cards were thereafter read using the Banjo ${ }^{\circledR}$ reader

Statistical analysis: The statistical package SPSS (Statistical Package for Social Sciences) software version 20 was used for data entry and analysis. Data was summarized by appropriate statistical tools such as mean, median, standard deviation; frequencies and proportion. The statistical significance was tested using the chi square and Fisher's test. P values less than or equal to 0.05 were considered as statistically significant.

\section{Results}

A total of 186 patients with chronic kidney disease participated in the study. They comprised of 124 patients with history of multiple blood transfusions and sixty-two (62) patients without a history of blood transfusion. The cases and controls were well-matched for sex and age as shown in table 1.

Table 1: AGE AND SEX DISTRIBUTION OF PATIENTS WITH CHRONIC KIDNEY DISEASE

\begin{tabular}{|c|c|c|c|c|}
\hline $\begin{array}{r}\text { AGE RANGE } \\
\text { (YEARS) }\end{array}$ & $\begin{array}{r}\text { MULTI-TRANSFUSED CKD } \\
\text { PATIENTS }(n=124)\end{array}$ & $\begin{array}{r}\text { NON-TRANSFUSED CKD } \\
\text { PATIENTS }(n=62)\end{array}$ \\
\hline & MALE (n/\%) & FEMALE $(n / \%)$ & MALE $(n / \%)$ & FEMALE $(n / \%)$ \\
\hline$<20$ & $5(7.4)$ & 0 & 0 & 0 \\
\hline $20-29$ & $7(10.3)$ & $9(16.1)$ & $2(5.3)$ & $3(12.5)$ \\
\hline $30-39$ & $6(8.8)$ & $15(26.8)$ & $7(18.4)$ & $5(20.8)$ \\
\hline $40-49$ & $20(29.4)$ & $7(12.5)$ & $14(36.8)$ & $9(37.5)$ \\
\hline $50-59$ & $14(20.5)$ & $139(23.2)$ & $2(5.3)$ & $3(12.5)$ \\
\hline$>60$ & $16(23.5)$ & $12(21.4)$ & $13(34.3)$ & $4(16.6)$ \\
\hline Total & $\mathbf{6 8 ( 1 0 0 )}$ & $\mathbf{5 6 ( 1 0 0 )}$ & $\mathbf{3 8 ( 1 0 0 . 0 )}$ & $\mathbf{2 4}(\mathbf{1 0 0 . 0 )}$ \\
\hline
\end{tabular}


Among the multi-transfused patients, the mean serum creatinine and urea were $906.2 \pm 631.2 \mathrm{mmol} / \mathrm{l}$ and 28 $\pm 9.8 \mathrm{mmol} / 1$ respectively compared to $608.9 \pm 392.9$ $\mathrm{mmol} / \mathrm{l}$ and $20.4 \pm 12.4 \mathrm{mmol} / 1$ respectively for the controls. The differences in creatinine and urea in the subjects and controls were not statistically significant as shown in table 2. The mean estimated GFR for the subjects was $24 \mathrm{mls} / \mathrm{min} / 1.73 \mathrm{~m}^{2}$ compared to $62 \mathrm{mls} /$ minute $/ 1.73$ $\mathrm{m}^{2}$ for the controls. This value was statistically significant (p-value $<0.005)$.
Seven hundred and eight-nine [789] units of blood were received by the multi-transfused patients. The number of units transfused per patient ranged from 2 to 34 with a mean and standard deviation of $6 \pm 6$ units.

Prevalence of red cell alloimmunization: Antibody screening was positive in five of the multi-transfused CKD patients. None of the controls had a positive antibody screen. Alloantibodies were identified in four of the multi-transfused patients and one of them had an autoantibody.

TABLE 2: Baseline characteristics of patients with chronic kidney disease.

\begin{tabular}{|l|l|l|l|}
\hline VARIABLE & $\begin{array}{l}\text { MULTIPLY TRANSFUSED } \\
\text { CKD PATIENTS }\end{array}$ & $\begin{array}{l}\text { NON-TRANSFUSEDCKD } \\
\text { PATIENTS }\end{array}$ & P-VALUE \\
\hline WEIGHT $(K G)$ & $68.7 \pm 14.5$ & $77.8 \pm 12.5$ & 0.112 \\
\hline HEIGHT $(\mathrm{CM})$ & $170.8 \pm 12$ & $171.2 \pm 13$ & 0.904 \\
\hline Creatinine $(\mu \mathrm{mol} / \mathrm{L})$ & $906.2 \pm 631.2$ & $608.9 \pm 392.9$ & $<0.0001^{*}$ \\
\hline Urea $(\mathrm{mmol} / \mathrm{L})$ & $28 \pm 9.8$ & $20.4 \pm 12.4$ & $<0.0001^{*}$ \\
\hline eGFR $(\mathrm{mls} / \mathrm{mins} / 1.73 \mathrm{~m} 2)$ & 24 & 26 & $<0.0001^{*}$
\end{tabular}

eGFR: estimated glomerular filtration rate.

Values are expressed as mean \pm SD

*Indicates difference is statistically significant $(p<0.05)$

The alloimmunized multi-transfused patients had a higher mean number of units transfused (17.5 \pm 12 units) compared to the non-alloimmunized multi-transfused patients which had a mean of $6 \pm 6$ units, and this was statistically significant $(\mathrm{p}=0.001)$.

Among the subjects, females had a higher alloimmunization rate of $2.4 \%(n=3)$ compared to the males $0.8 \%$ $(\mathrm{n}=1)$. Females were 2.2 times more likely to develop alloantibodies than the males, however this association was not significant (odds ratio $=2.2,95 \%$ Confidence Interval $=0.193-26.154$. Of the 3 females who were alloim- munised, one was nulliparous while the other two were multiparous.

Frequency, specificity and titre of red cell alloantibodies: A total of 6 alloantibodies were detected in the alloimmunised, three patients developed double alloantibodies while one developed triple alloantibodies [table 3]. Anti $\mathrm{E}$ was detected in all four multi-transfused alloimmunised patients while the other antibodies detected were anti Jka, anti C, anti D, anti Fya and anti M respectively [table 3]. 
Table 3: Characteristics of alloimmunized multi-transfused chronic kidney disease patients.

\begin{tabular}{|c|c|c|c|c|c|}
\hline S/NO & AGE & SEX & $\begin{array}{l}\text { TRANSFUSIONS } \\
\text { RECEIVED (N) }\end{array}$ & $\begin{array}{l}\text { ALLOANTIBODIES } \\
\text { IDENTIFIED (N) }\end{array}$ & $\begin{array}{l}\text { ANTIBODY } \\
\text { SPECIFICITY }\end{array}$ \\
\hline 1 & 40 & Male & 9 & 2 & Anti-Jka, Anti-E \\
\hline 2 & 38 & Female & 10 & 2 & Anti E Anti- Fya \\
\hline 3 & 32 & Female & 34 & 2 & Anti-E Anti-M \\
\hline 4 & 22 & Female & 17 & 3 & $\begin{array}{l}\text { Anti-C } \\
\text { Anti-E } \\
\text { Anti-D }\end{array}$ \\
\hline
\end{tabular}

\section{Figure 1: Antibody screening using the gel card}

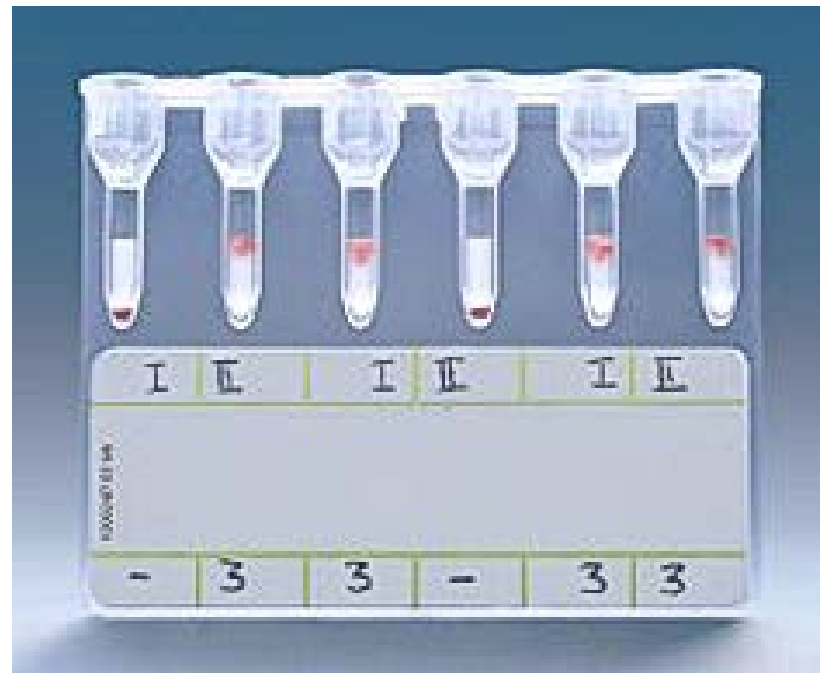

The frequency of anti $\mathrm{E}$ among the multi-transfused ESRD patients was $3.2 \%$ while the other antibodies each showed frequency of $0.8 \%$ each as shown in figure 2 . Two of them had a titre of 1024 while the others had titres of 512 and 32 respectively. The multi-transfused pa- tients with the highest titre developed antibodies to anti $\mathrm{E}$, anti- $\mathrm{M}$ and anti Fy.a

The risk of alloimmunization per unit of blood, defined ${ }^{19}$ as the total number of alloantibodies detected (6), divided by the total number of transfused units (789) multiplied by 100 , was $0.76 \%$ for the multi-transfused CKD patients. 
Figure 2: Prevalence of alloantibodies among multi-transfused chronic kidney disease patients

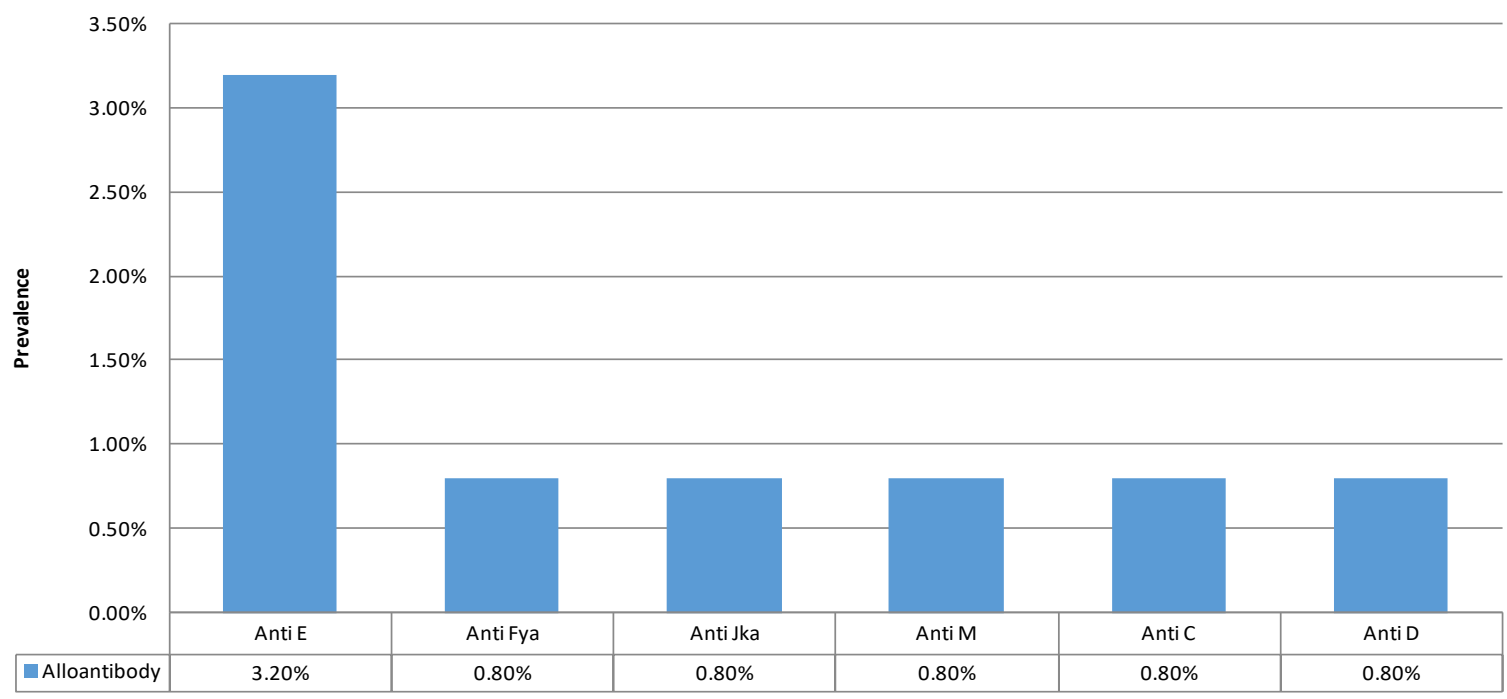

\section{Discussion}

Blood transfusion may be life-saving in chronic kidney disease (CKD) as it promptly improves the oxygen-carrying capacity in patients with symptomatic anaemia. However, transfusion-transmissible infections (TTI) and alloimmunisation are potential complications especially in multi-transfused patients. In our study, there were more males with CKD compared to females similar to the findings of iseki et al. ${ }^{20}$

The prevalence of red cell alloimmunization among multi-transfused patients with CKD in this study was $3.2 \%$. None of the controls had alloantibodies. This prevalence is lower than that reported by shuklla et $\mathrm{al}^{21}$ $(9.8 \%)$ and Babiker et $\mathrm{al}^{22}(13.1 \%)$. The difference could be due to varied geographical locations of the studies as prevalence of antigens varies with geographical locations. ${ }^{23}$ A higher prevalence may also have been seen in this study if serial antibody screening test were done on these study participants. Red blood cell non-ABO blood group alloantibodies has been shown to evanescence over time confounding compatibility testing and predisposing patients to delayed haemolytic transfusion reactions. ${ }^{23}$ The mean number of blood units transfused in this study was significantly higher in individuals that developed RBC alloantibodies. This might be because the multi-transfused patients were exposed to more donors with different genetic makeup. Natukunda et $\mathrm{al}^{12}$ and San- tos et $\mathrm{al}^{24}$ also reported higher prevalence of alloantibody formation in recipients who received the more transfusions. The mean number of blood units received by the cases was $17.5 \pm 12$, which is in concordance with reports that multi-transfused patients who developed received 16 to 25 units of blood. ${ }^{24,25}$ The risk of alloimmunization in this study was $0.76 \%$, and this is within the reported range of 0.5 to $5.9 \%$ seen in the literature. ${ }^{24,25,26}$

In our study, the rate of alloimmunization was not significantly influenced by sex which is contrary to what was reported by Babiker et al, ${ }^{27}$ Silvia et $\mathrm{al}^{28}$ and Zaman et $\mathrm{al}^{29}$ who found a higher prevalence in women, but similar to the findings of Shukla et al. ${ }^{30}$ We also observed that all the alloimmunised patients developed multiple antibodies contrary to the findings of Skulla ${ }^{30}$. This may be attributed to genetic differences, and lack of routine pretransfusion antibody screening test in this environment which increases the tendency to develop an additional alloantibody after subsequent transfusions.

In concordance with other studies, the most frequent red cell antibodies in our study were against the $\mathrm{E}$ antigen (figure 2) of the $\mathrm{Rh}$ blood group system. ${ }^{31,32,33}$ The frequency of the $\mathrm{E}$ antigen is generally low in blacks (about $21 \%$ ), as such multi-transfused patients who were hitherto lacking the $\mathrm{E}$ antigen are likely to develop anti-E from transfusions. ${ }^{34}$ In addition, anti-E has been found 
to be the commonest alloantibody during routine screening and this is probably because half the anti-E are weak, naturally occurring Ig $\mathrm{M}$ antibodies ${ }^{35}$. A study in Kano, Nigeria showed a low distribution of Rh E (34\%), which further suggests a higher likelihood of recipients developing alloantibodies to it. ${ }^{36}$

The other identified antibodies which showed the least combination were anti-M, anti-Jka and anti-Fya and this is similar to other reports. ${ }^{37}$ Anti $\mathrm{M}$ is a naturally occurring cold antibody and is often not reactive at $37^{\circ} \mathrm{C}$ and with anti-human globulin [AHG] reagent, except when present in very high titre. ${ }^{38}$ However, a small percentage of anti-M is of the immune type and can elicit haemolytic transfusion reactions. ${ }^{39}$ Studies show that two-thirds or more of blacks are negative for Duffy antigen Fy (ab-), and in Nigeria, the prevalence of anti-Fya is about $4.3 \%{ }^{39}$ Similarly, the prevalence of anti JKa was reported as $4.9 \%$ in Nigeria. ${ }^{40}$

The highest antibody titre observed in this study was 1024 while the least was 4 . One of the multi-transfused patients developed an autoantibody and this can lead to shortened red cell life span, predisposing the patient to further transfusions ${ }^{28}$. One of the multi-transfused patients that was Rh D positive, developed antibodies to the $\mathrm{Rh} \mathrm{D}$ antigen. This suggests that this patient might have had a partial D. Persons of African origin have been reported to show the presence of numerous $R$ h variants. ${ }^{41,42}$ In addition, patients in this environment are not usually phenotyped for the partial-D variant; hence there may be a propensity to develop antibodies to the $\mathrm{Rh} \mathrm{D}$ antigen. Studies have shown that HLA alloimmunization is associated with RBC antibodies in multiply transfused sickle cell patients. This may result in graft rejection during stem cell or organ transplantation. ${ }^{43}$

\section{Conclusion}

This study showed that 3.2\% of the multi-transfused patients with CKD developed alloantibodies most of which were of the Rh phenotype. These alloantibodies may lead to allograft rejection, or even poor patient survival. Thus we advocate that renal transplant be instituted at the earliest opportunity whenever it becomes inevitable as a modality of treatment to enhance better outcomes.

\section{Conflict of interest}

Authors have declared there are no conflicting interests.

\section{References}

1. Ulasi II, Ijoma CK. The enormity of chronic kidney disease in Nigeria: The situation in a Teaching Hospital in South-East Nigeria. 2010 [cited 2013 4th January]; http:/ / www.ncbi.nlm.nih.gov/pmc2896838/pdf/JTM28920102501957.pdf].

2. Kidney Disease Outcomes Quality Initiative. Definition and Classification of Stages of Chronic Kidney Disease. K/DOQI Clinical Practice Guidelines for chronic disease, evaluation, classification, and stratification. New York: National Kidney foundation; 2002. p. 43 - 75.

3. Kidney Disease Improving Global Outcomes-Clinical Practice Guidelines for anaemia in chronic kidney disease. Red cell transfusion to treat anaemia in CKD. Kidney International supplements. 2012;2(4):311 - 316.

4. Arogundade FA, Ijoma CK, Awobusuyi JO, Asinobi A, Amira CO, Adamu B, et al. Guidelines for the detection and management of chronic kidney disease. Tropical Journal of Nephrology. 2011;6(1):19 - 30.

5. Schonewille H, Watering L, Loomans D, Brand A. Red blood cell alloantibodies after transfusion: factors influencing incidence and specificity. Transfusion. 2006;46(2):250 PubMed -256.

6. Fox KM, Yee J, Cong Z, Brooks JM, Peterson J, Lamerato $\mathrm{L}$, et al. Transfusion burden in non-dialysis chronic kidney disease patients with persistent anaemia treated in routine clinical practice: a retrospective observational study. BioMed Central Nephrology. 2012;13(5):1 - 8.

7. Zalpuri S, Zwaginga JJ, Van der Bom JG. Risk factors for Alloimmunization after red blood Cell Transfusions : a case cohort study. BMJ. 2012;2:1-7 PubMed.

8. Hassab AH, Sorour AF, Ahmed MI, Salama MA, Aly $\mathrm{Ak}$. Antibody screening in repeatedly-transfused patients. Egypt J Immunol. 2008;15(2):1 PubMed - 14.

9. Thakral B, Saluja K, Sharma RR, Marwaha N. Red cell alloimmunization in a transfused population: a study from a tertiary hospital in North India. Haematology. 2008;13(5):313 - 318.

10. Natukunda B, Brand A, Schonewille H. Red blood cell alloimmunization from an African perspective. Curr Opin Hematol. 2010;17(6):565 -570. PubMed Epub 2010/09/10.

11. Natukunda B, Schonewille H, Ndugwa C, Brand A. 
Red blood cell alloimmunization in sickle cell anaemia patients in Uganda. Transfusion. 2010;50(1):20-25. PubMed. 12. Natukunda B, Schonewille H, Van de Watering L, Brand A. Prevalence and specificities of red blood cell alloantibodies in transfused Ugandans with different diseases. Vox Sang. 2010;98(2):167-171. PubMed

13. Gwarzo KA, Akanmu AS, Dutse AI. Prevalence of red cell alloantibodies in multi-transfused patients with sickle cell anaemia in nothern Nigeria. Africa Sanguine. 2005;8(1):1-4. PubMed

14. United States Renal disease System 2010 Annual Data Report: Atlas of Chronic Kidney Disease and End-Stage Renal Disease in the United States. National institutes of Health 2010, National Institute of Diabetes and Digestive and Kidney Diseases: United States Renal Disease System.

15. Mishra MN, Baliga KV. Significance of panel reactive antibodies in patients requiring kidney transplantation. Saudi Journal of Kidney Diseases and Transplantation. 2013;24:495 -499.

16. Haslina MNN, Ariffin N, Hayati II, Roseline H. Red cell immunization in multiply transfused Malaysian thalassaemic patients. SouthEast Asian J Trop Med Public Health. 2006;37(5):1015 -1020.

17. Klein HG, Anstee DJ. Blood Grouping techniques. Mollison's Blood Transfusion in Clinical medicine. Eleventh ed. United Kingdom: Blackwell; 2005. p. 299 - 342. 18. Promwong C, Siammai S, Hassarin S, Buakaew J, Yeela $\mathrm{T}$, Soisangwan $\mathrm{P}$, et al. Frequencies and specificities of red cell alloantibodies in the Thai population. Asian Journal of Transfusion Science. 2013;7(1):16 - 20.

19. Precision of alloabtibody titration in gel vs tubes AABB. [cited 2014 28th July ]; www.aabb.org/developments/scholarships/Documents/12scabet.pdf].

20. Iseki K. Gender differences in chronic kidney disease. Kidney International. 2008;74:415 - 417. 21. Shuklla JS, Chaudhary RK. Red cell alloimmunization in multi-transfused chronic renal failure patients undergoing hemodialysis. Indian J Pathol Microbiol. 1999;42(3):299 - 302.

21. Shuklla JS, Chaudhary RK. Red cell alloimmunization in multi-transfused chronic renal failure patients undergoing hemodialysis. Indian J Pathol Microbiol. 1999;42(3):299 $-302$.

22. Babiker HAM, Elsayed TY. Frequency of alloantibodies among chronic renal failure patients in red sea state. Indian Journal of Haematology and Blood Transfusion. 2013;30(3):187 - 190.

23. Tormey CA, Stack G. The persistence and evaesnes- cence of blood group antibodies in men. Transfusion. 2009:49(3): 505 PubMed -512.

24. Santos FW, Magalhaes SM, Mota RM, Pitombeira MH. Post-transfusion red cell alloimmunization in patients with acute disorders and medical emergencies. Rev Bras Hematol Hemoter. 2007;29(4):369 - 372.

25. Schonewille H, Haak HL, Zijl AMV. Alloimmunization after blood transfusion in patients with haematologic and oncologic diseases. Transfusion. 1999;39:763 - 771 PubMed.

26. Shuklla JS, Chaudhary RK. Red cell alloimmunization in multi-transfused chronic renal failure patients undergoing hemodialysis. Indian J Pathol Microbiol. 1999;42(3):299 -302 .

27. Babiker HAM, Elsayed TY. Frequency of alloantibodies among chronic renal failure patients in red sea state. Indian Journal of Haematology and Blood Transfusion. 2013;30(3):187 - 190.

28. Silvia SF, Alves TM, Ribeiro TR. Red blood cell and leukocyte alloimmunization in patients awaiting kidney transplantation. Rev Bras Hematol Hemoter. 2013;35(3):185 - 188.

29. Zaman S, Chaurasia R, Chatterjee K, Thapliyal RM. Prevalence and specificity of RBC alloantibodies in Indian patients attending a tetiary hospital. 2014 [cited 2014 Noveber 20th]; http://www.hindawi.com/journals/ ah/2014/749218/].

30. Shuklla JS, Chaudhary RK. Red cell alloimmunization in multi-transfused chronic renal failure patients undergoing hemodialysis. Indian J Pathol Microbiol. 1999;42(3):299 $-302$.

31. Tormey CA, Gary. S. The characterization and classification of concurrent blood group antibodies. Transfusion. 2009;49(12):2709 PubMed - 2718.

32. Zaman S, Chaurasia R, Chatterjee K, Thapliyal RM. Prevalence and specificity of RBC alloantibodies in Indian patients attending a tetiary hospital. 2014 [cited 2014 Noveber 20 th ; http://www.hindawi.com/journals/ ah/2014/749218/].

33. Joudi AF, Ali AB, Ramli MB, Ahmed S, Ishmail M. Prevalence and Specificities of red cell antibodies among blood recipients in Malaysian State of Kelantan. Asian Journal of Transfusion Sience. 2011;5(1):42-45.

34. Reid ME. Erythrocyte Antigens and antibodies. In: Kaushansky K, Lichtman MA, Beutler E, Kipps TJ, Seligsohn U, Prchal JT, editors. Williams Haematology. Eight ed. China: Mc Graw Hill; 2008. p. 2247-2285.

35. Nwauche C.A, Ejele O.A. Rhesus immunization in 
Nigeria: Current Status. Nigerian Journal of Clinical Practice. 2003;6(2):107 110.

36. Gwaram BA, Abdullahi S. Prevalence of Rh phenotypes among blood donors in Kano, Nigeria. African Journal of Medicine. 2013;15(1):37 -39.

37. Schonewille H, Brand A. Does an alloimmune response to strong immunogenic red blood cell antigens enhance a response to weaker antigens? Transfusion. 2008;48(5):958 PubMed - 996.

38. Tondon R, Kataria R, Chaudhary R. Anti-M: Report of two cases. Asian J Transfus Sci. 2008;2(2):81-83.

39. Erhabor O, Shehu CE, Alhaji YB, Yabuku A. Duffy red cell phenotypes amongst pregnant women in Sokoto, North Western Nigeria. Blood Disorders and Transfusion. 2014;5(7):223 - 227.
40. Erhabor O, Hassan M, Alhaji YB, Yakubu A, Buhai H. Kidd blood group phenotypes among pregnant women in Sokoto, North Western Nigeria. Asian Pacific Journal of Medicine. 2014;7(Supplement 1):S111 - S115.

41. Yazdanbakhsh K,Ware RE, Noizat-pirenne F. Red blood cell alloimmunization in sickle cell disease: pathophysiology, risk factors, and transfusion management. Blood. 2012;120:528 - 537.

42. Flegel WA. Molecular genetics of Rh and its clinical implication. Transfus Clin Biol. 2006;13(1):4 PubMed -12 43. McPherson ME, Anderson AR, Josephson CD. HLA alloimmunization associated with RBC antibodies in multiply transfused patients with sickle cell disease. Pediatr Blood Cancer. 2010;54(4):552-558. 